\title{
DESPERTANDO O OLHAR EMPREENDEDOR EM ESTUDANTES DE QUÍMICA: VIVÊNCIA E EXPERIÊNCIA
}

Congresso Nacional Online de Empreendedorismo, 3ạ edição, de 06/12/2021 a 08/12/2021 ISBN dos Anais: 978-65-81152-30-7

CRUZ; Rodrigo Ramos da 1, SILVA; Hildelayne Ferreira da 2, CRUZ; Randerson Ramos da 3

\section{RESUMO}

As rápidas transformações tecnológicas, econômicas e a globalização vão criando a cada momento novas necessidades, trazendo assim novas demandas às mais diversas áreas profissionais. O empreendedorismo sempre foi tido como área intimamente ligada à administração. Entretanto, nos últimos anos, essa palavra vem encontrando mercados em áreas bem distintas como medicina, direito, biologia entre outras. 0 novo profissional do século XXI precisa ter consigo características empreendedoras, não somente no intuito de criar novos empreendimentos, mas também para poder ajudar no desenvolvimento da organização em que está inserido, ao criar novas oportunidades ou resolucionar problemas. Empreender, portanto, pode ser a saída para se reinventar e se destacar em mercados cada vez mais saturados ou com oportunidades cada vez mais escassas e específicas. Este estudo, portanto, busca relatar a experiência de palestras sobre empreendedorismo e características empreendedoras ministradas em turmas de um curso de química, em uma Universidade Maranhense. Dada a impossibilidade de realizar as conversas em modo presencial, dois professores do curso de química convidaram um administrador para ministrar essas palestras de modo remoto. A primeira palestra fora intitulada "Noções Básicas de Empreendedorismo" e aplicada dentro da disciplina Botânica Econômica. Nesta palestra, fora dado um espaço para que os discentes pudessem perceber como a utilização do conhecimento científico pode ser uma ferramenta de grande diferenciação no mercado, simulando assim, a partir das ideias obtidas em aula, a criação de pequenos negócios. Num segundo momento, foi dada a palestra "Seja empreendedor, use a química a seu favor". Nessa conversa, o público alvo passou a ser alunos em fase de conclusão de curso, que dada a pandemia e as poucas oportunidades de trabalho encontradas no período, encontravam-se em dúvidas sobre o que fazer com o tão sonhado diploma, e onde iriam trabalhar. Percebeu-se, portanto, a importância destas duas conversas para despertar em jovens com poucas oportunidades, o espírito de crescimento individual e profissional, além de evidenciar que todo o conhecimento adquirido na academia poderia se tornar um diferencial em sua carreira empreendedora. Desse modo, o objetivo inicial das palestras traçados pelos professores organizadores e palestrantes foi alcançado: o de despertar uma visão diferenciada nos discentes, fazendo com que seus pensamentos estejam cada vez mais abertos, e suas visões estejam cada vez mais atentas à novas oportunidades. Entretanto, em contrapartida, notou-se um tanto de receio 
para tomar iniciativas, e evidenciou-se problemas clássicos como: "falta de investimento", "necessidade de segurança/estabilidade", "medo do novo" e "medo do fracasso. Contudo, as palestras instigaram os discentes a se aprofundarem no assunto. Nesse sentido, identificou-se a necessidade de uma formação empreendedora dentro do curso, para que mesmo em período pequeno, seja possível discutir, incentivar e desenvolver competências, habilidades e características que ajudem o aluno a potencializar suas aptidões.

PALAVRAS-CHAVE: Empreendedorismo, docencia, visão empreendedora 